Z. WANG, J. SHI, J. WANG, C. LI, X. TIAN, Y. CHENG,*H. WANG* (HENAN UNIVERSITY, KAIFENG, LUOYANG NORMAL UNIVERSITY AND CHANGCHUN INSTITUTE OF APPLIED CHEMISTRY, P. R. OF CHINA)

Syntheses and Crystal Structure of Benzohexathia[7]helicene and Naphthalene Cored Double Helicene Org. Lett. 2010, 12, 456-459.

\title{
Helicene and Double Helicene
}<smiles></smiles>

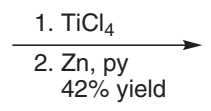

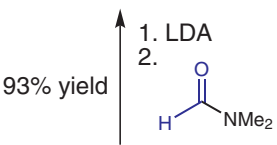<smiles>CS(=O)(=O)c1cc2c(-c3csc4sc5scc(S(C)(=O)=O)c5c34)csc2s1</smiles>

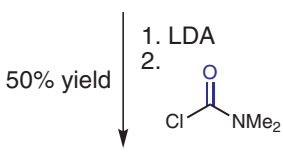

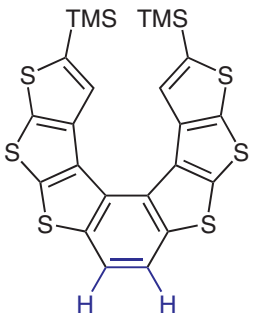

3

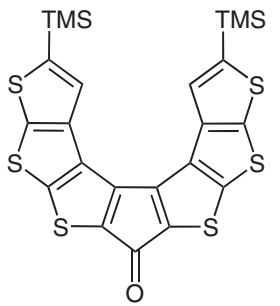

Gategory

Synthesis of Materials and

Unnatural Products

Key words

helicenes

naphthalenes

McMurry reaction

thiophenes

SYNFACTrent
Significance: A high-yield synthesis of three novel helicene compounds (3, 5 and $\mathbf{6}$ ) was developed. X-ray single-crystal structure analysis revealed multiple intermolecular short contacts and UV/Vis spectra indicate significant $\pi$-delocalization in double helicene $\mathbf{6}$, indicating potential in organic functional materials.
Comment: The efficient synthesis of $\mathbf{1}$ can be achieved in a total yield of $28 \%$ from 3-bromothiophene (J. Org. Chem. 2009, 74, 408). 